\title{
Identification of some wild Vicia species using electrophoretic analysis of seed proteins and amino acids composition
}

\author{
M.M. Sakr ${ }^{1}$, S.M.H. Gowayed ${ }^{2}$, W.M. Hassan ${ }^{2}$ and O.A. Almghraby ${ }^{2}$ \\ ${ }^{1}$ Dept. of Science, Education College, King Abdul-Aziz University, Jeddah, Saudi Arabia \\ ${ }^{2}$ Agricultural Botany Department, Faculty of Agriculture, Suez Canal University, Ismailia, Egypt \\ salahgowed@yahoo.com
}

\begin{abstract}
We studied protein variation among the Egyptian species of wild Vicia that may be of taxonomical importance. Seeds of five wild Vicia species (Vicia sativa subsp. amphicarpa, V. articulata, V. ervilia, V. narbonensis and V. villosa) were collected from their natural habitats in Egypt. Protein, albumin and globulin electrophoresis was carried out on the seeds. Moreover, protein content and its amino acids, albumin and globulin were determined. Total bands and their distribution and similarity percentage differed according to the studied Vicia species and protein type. Generally, the highest values of total bands for total protein, albumin and globulin were observed in $V$. sativa subsp. amphicarpa. Amount of albumin, globulin, total protein, albumin/total protein, globulin/ total protein and amino acids varied according to the studied Vicia species. In general, the highest values of determined amino acids, albumin/total protein and globulin/ total protein ratio were recorded in $V$. articulata. Furthermore, numerous taxonomical markers were observed for each studied Vicia species on basis of total protein, albumin and globulin electrophoresis. These identity electrophoregram of the studied species can be used as a tool for identifying the genetic diversity in Vicia species. These results support the validity of seed protein as a powerful tool for Vicia species identification and clarifying taxonomic relationships
\end{abstract}

Keywords: Vicia, electrophoresis, seed proteins, dendogram, amino acids, legume, gentic diversity, taxonomy

\section{Introduction}

Täckholm (1974) recognized twelve species of Vicia in Egypt; where as Boulos (1999) enumerated fourteen species. The genus Vicia belongs to the tribe Vicieae, Papilionoideae and Fabaceae. The legumes are a diverse and important family of angiosperms, with more than 650 genera and 18000 species, legumes are the third largest family of higher plants and are second only to grasses in agricultural importance (Young et al., 2003). Seed storage protein is important for taxonomical studies (Ladizinsky \& Waines 1982; Miege, 1982; Vaughan 1983). Moreover, they used protein for identification the geographical origin of different taxa, determination of parents in hybrid species, characterization of polyploids and amphiploids and establishment of similarities between species and the formulation of hypotheses on their phylogeny. They suggested that variation in the seed proteins of Vicia sativa might be an important agent for acquiring ecological flexibility. Daussant et al. (1983) found that the protein content of the legume seeds ranged from $19-30 \%$, rarely less than $20 \%$ and often more. Rao (1984) found that Vicia faba albumins composed of approximately about $21 \%$ from total seed proteins; but globulins represented about $70 \%$ of total seed proteins. On the other hand, Muntz et al. (1986) reported that Vicia faba globulins composed of approximately $30 \%$ vicilin and $70 \%$ legumin. Przybylska et al. (1992) indicated that $2 \mathrm{~s}$ albumin is characteristic for tribe Vicieae and important for its systematic. Potokina et al. (2000) used both seed protein and RAPDs to study intraspecific variation between taxa in $V$. sativa aggregate and found considerable genetic divergence between and within the studied taxa. They added that seed protein patterns are an effective tool for identifying accessions that can not be identified clearly by morphological criteria alone. Mirali et al. (2007) found major differences in the frequencies of the electrophoretic profiles in the different Vicia species and showed that the abundance of polymorphisms in cross-fertilised species is much higher than those of self-fertilized ones. Moreover, Mustafa (2007) analyzed seed albumins of nine Egyptian cultivars of Vicia faba and identified the electrophoregram profile for each cultivar and assessing genetic variation. Also, he found negative correlation between seed globulins and albumins.

Jackson et al. (1969) isolated the amino acids; aspartic, glutamic, threonine, serine, glycine, valine, I/2 cystine, methionine, isoleucine, tyrosine, phenylalanine, lysine, histidine and arginin from Vicia faba seeds. Glutamic and aspartic acid residues were predominate in protein seeds, whereas; cystine and methionine residues were inconspicuous. Also, Bailey and Boulter (1970) found that the protein of Vicia faba consisted of aspartic, threonine, serine, glutamic, proline, glycine, alanine, methionine, isoleucine, tyrosine, phenylalanine, lysine, histidine and arginine acids. On the other hand, Hassan (1997) determined amino acids ( $\mu \mathrm{mol} / \mathrm{g}$ dry wt.) existing in the seeds of seven Vicia species; $V$. cinerea, $V$. 
cordata, $V$. faba cv. Giza2, V. monantha, $V$. nigra, $V$. peregrina and $V$. sativa and found the highest values for most determined amino acids; arginine (0.42), glutamine $(0.005)$, serine $(0.37)$, aspartic $(0.69)$, glutamic $(0.75)$, theronine $(0.24)$, glycine $(0.42)$, alanine $(0.37)$, methionine $(0.04)$, valine $(0.24)$, leucine $(0.34)$, lysine (0.63) and total determined amino acids (4.94) $(\mu \mathrm{mol} / \mathrm{g}$ dry wt.) were recorded in $V$. sativa in comparison with the other species.

The objective of this paper is studying the variations in protein, albumin and globulin electrophoresis, in addition, protein, albumin, globulin and amino acids content among studied Vicia species to their identification.

\section{Materials and methods}

Seeds of five Vicia species, $V$. sativa subsp. amphicarpa, V. articulata, V. ervilia, V. narbonensis and $V$. villosa were collected from their natural habitats in Egypt. Protein, albumin and globulin electrophoresis was carried out on the seeds of five Vicia species. In addition, protein content and its amino acids were determined as follows:

\section{Protein electrophoresis}

Seed cotyledons of five studied Vicia species were separated and ground to powder in a mortar after removing the testa, $0.5 \mathrm{~g}$ of the powder was defatted twice with $25 \mathrm{ml} 70 \%$ ethanol for $10 \mathrm{~min}$ each. All the following steps were carried out at $4^{\circ} \mathrm{C}$. Total seed proteins were extracted with extraction buffer $(0.1 \mathrm{~g} / \mathrm{ml})$ which composed of $20 \mathrm{mM} \mathrm{Na}$-borate buffer, $0.5 \mathrm{M} \mathrm{NaCl}$, $1 \mathrm{mM}$ ethylenediaminetetra-acetic acid (EDTA), $\mathrm{pH}$ 8.9. After $12 \mathrm{~h}$ of stirring, the extract was centrifuged at $10,000 \mathrm{~g}$ for $20 \mathrm{~min}$. The supernatant was the total protein; $10 \mu \mathrm{l}$ of it was taken for electrophoresis or stored at $-20^{\circ} \mathrm{C}$ according to Juo and Stotzky (1970) and Tucci et al. (1991). Sodium dodecyle sulphate polyacrylamide gel electrophoresis (SDS-PAGE) was carried out in $10 \%$ acrylamide slab gels according to Laemmli (1970).

\section{Albumin \& globulin electrophoresis}

The above supernatant (total protein) was filtered into dialysis bags by running distilled water for $48 \mathrm{~h}$. This homogenate was centrifuged at $10,000 \mathrm{~g}$ for $20 \mathrm{~min}$. The supernatant was albumin and the residue was saltsoluble protein (globulin), the residue was washed and suspended in $2 \mathrm{ml}$ from above mentioned extraction buffer. $20 \mu \mathrm{L}$ of albumin and $10 \mu \mathrm{L}$ of globulin were taken for electrophoresis according to Juo and Stotzky (1970). Gel electrophoresis was carried out in $10 \%$ acrylamide slab gels, with a current of $25 \mathrm{~mA}$ and 130 volts per gel until the bromophenol blue marker reached to the bottom of the gel. After electrophoresis, the gels were placed in the solution of coloration which was composed of $0.1 \%$ Coomassie blue $\mathrm{G}$ solution made of $1 \mathrm{gm}$ Coomassie blue G, $23.5 \mathrm{ml}$ phosphoric acid $85 \%$ and $10 \mathrm{~g}$ ammonium sulphate and were dissolved in 1 I distilled water at room temperature for $3 \mathrm{~h}$. Moreover, similarity matrix based on Jaccard's coefficient were estimated by cluster analysis using UPGMA method (Unweighted pair group method with Arithmetic mean) depending on the similarity polymorphism of total protein, albumin and globulin patterns based in protein marker. All computations were performed with NTSYS-PC version 2.1 (Rohlf, 1993).

\section{Determination of protein content}

Albumin, globulin and total protein were determined according to Bradford (1976).

\section{Determination of amino acids}

Amino acids (arginine, aspargine, glutamine, serine, asparatic, glutamic, threonine, glycine, alanine, methionine, valine, phenylalanine, isoleucine, leucine, histidine, lysine and tyrosine) were determined using computerized High Performance Liquid Chromatography (HPLC) apparatus. Preparation, purification and determination of such samples were described by Moore and Stein (1963). One gram of Vicia species cotyledons was ground in a mortar to powder. The powder was defatted with acetone (3 times) and filtered with filter paper using water pump to obtain the acetone powder. Five $\mathrm{mg}$ of each acetone powder was placed into a $16 \mathrm{x}$ $125 \mathrm{~mm}$ heavy-walled Pyrex test tube, $1 \mathrm{ml} 6 \mathrm{~N} \mathrm{HCl}$ was added to test tube, and then closed tightly by flame of oxygen. All samples were placed in oven at $110^{\circ} \mathrm{C}$ for 24 $\mathrm{h}$ for hydrolysis. After hydrolysis, the tube was opened carefully and the samples were dried under vacuum in a water bath at 40 to $45^{\circ} \mathrm{C}$ using water pump. The residues were dissolved in $0.5 \mathrm{ml}$ of distilled water, transferred to $15 \mathrm{ml}$ conical flask and $0.5 \mathrm{ml}$ of $0.2 \mathrm{M}$ sodium phosphate buffer were added. These extracts were, then, evaporated under vacuum to complete dryness. The dried residues were dissolved in $5 \mathrm{ml}$ of sodium phosphate buffer, shacked and then filtered through $0.2 \mu$ membranes. After filtration, 20-75 $\mu$ of such cotyledons extracts were taken and injected in HPLC apparatus for estimating the different types of amino acids.

\section{Results}

Generally, the protein electrophoresis was appropriated to determine the differences and genetic diversity among the five studied Vicia species by cluster analysis using UPGMA depending on the similarity polymorphism of total protein, albumin and globulin patterns. Similar trend was found in this concern in relation to amino acids profile.

\section{Total protein electrophoresis}

The electrophoretic data of albumin, globulin and total protein fractions existing in the studied five Vicia species seed, which have been investigated using SDS-PAGE, are presented in Table 1-6 and Fig. 1-6. It is clearly shown from these Tables and Figures that albumin, 
Table 1. Seed total protein banding patterns of studied Vicia species obtained by SDS-PAGE.

\begin{tabular}{|c|c|c|c|c|c|c|c|}
\hline $\begin{array}{l}\text { Band } \\
\text { No. }\end{array}$ & $\begin{array}{c}\mathrm{MW} \\
(\mathrm{KDa})\end{array}$ & 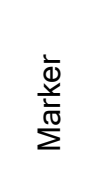 & 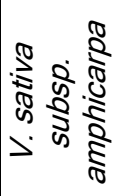 & 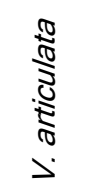 & 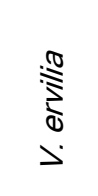 & 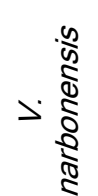 & $\begin{array}{c}0 \\
\infty \\
\stackrel{0}{S} \\
>\end{array}$ \\
\hline 1 & 97 & 6.64 & 0.00 & 0.00 & 3.55 & 0.00 & 0.00 \\
\hline 2 & 92 & 0.00 & 0.00 & 0.00 & 0.00 & 5.40 & 0.00 \\
\hline 3 & 89 & 0.00 & 0.00 & 2.99 & 0.00 & 0.00 & 0.00 \\
\hline 4 & 87 & 0.00 & 4.35 & 0.00 & 0.00 & 0.00 & 0.00 \\
\hline 5 & 86 & 0.00 & 0.00 & 0.00 & 0.00 & 0.00 & 1.17 \\
\hline 6 & 83 & 0.00 & 0.00 & 0.00 & 0.00 & 0.00 & 1.13 \\
\hline 7 & 82 & 0.00 & 0.00 & 5.76 & 0.00 & 0.00 & 0.00 \\
\hline 8 & 73 & 0.00 & 0.00 & 0.00 & 7.12 & 0.00 & 0.00 \\
\hline 9 & 68 & 0.00 & 0.00 & 0.00 & 2.82 & 0.00 & 0.00 \\
\hline 10 & 66 & 12.99 & 0.00 & 0.00 & 0.00 & 0.00 & 0.00 \\
\hline 11 & 64 & 0.00 & 3.54 & 0.00 & 0.00 & 0.00 & 0.00 \\
\hline 12 & 62 & 0.00 & 2.33 & 0.00 & 1.07 & 0.00 & 8.32 \\
\hline 13 & 61 & 0.00 & 0.00 & 9.80 & 0.00 & 6.27 & 0.00 \\
\hline 14 & 59 & 0.00 & 3.12 & 2.56 & 2.59 & 0.00 & 0.00 \\
\hline 15 & 58 & 0.00 & 0.00 & 0.00 & 0.00 & 20.62 & 0.00 \\
\hline 16 & 57 & 0.00 & 1.56 & 0.00 & 11.86 & 0.00 & 0.00 \\
\hline 17 & 56 & 0.00 & 1.57 & 0.00 & 1.57 & 0.00 & 3.91 \\
\hline 18 & 55 & 0.00 & 4.31 & 0.00 & 0.00 & 0.00 & 0.00 \\
\hline 19 & 54 & 0.00 & 0.00 & 1.84 & 2.73 & 0.00 & 0.00 \\
\hline 20 & 53 & 0.00 & 1.58 & 0.00 & 0.00 & 3.11 & 0.00 \\
\hline 21 & 52 & 0.00 & 3.15 & 1.81 & 0.00 & 0.00 & 13.66 \\
\hline 22 & 50 & 0.00 & 1.58 & 3.62 & 1.35 & 0.00 & 3.12 \\
\hline 23 & 49 & 0.00 & 3.16 & 0.00 & 0.00 & 5.15 & 0.00 \\
\hline 24 & 48 & 0.00 & 0.00 & 2.18 & 0.00 & 0.00 & 0.00 \\
\hline 25 & 47 & 0.00 & 0.00 & 0.00 & 0.00 & 4.99 & 4.42 \\
\hline 26 & 46 & 0.00 & 22.92 & 0.00 & 10.54 & 4.29 & 0.00 \\
\hline 27 & 45 & 26.32 & 3.00 & 14.86 & 0.00 & 0.00 & 0.00 \\
\hline 28 & 44 & 0.00 & 0.00 & 2.10 & 1.99 & 0.00 & 0.00 \\
\hline 29 & 42 & 0.00 & 3.12 & 0.00 & 0.00 & 0.00 & 0.00 \\
\hline 30 & 41 & 0.00 & 0.00 & 1.30 & 0.00 & 0.00 & 0.00 \\
\hline 31 & 39 & 0.00 & 0.00 & 0.00 & 15.02 & 0.00 & 4.82 \\
\hline 32 & 38 & 0.00 & 3.45 & 3.43 & 1.98 & 8.68 & 0.00 \\
\hline 33 & 37 & 0.00 & 10.74 & 0.00 & 0.00 & 0.00 & 4.87 \\
\hline 34 & 36 & 0.00 & 7.54 & 4.25 & 3.55 & 8.07 & 2.08 \\
\hline 35 & 35 & 0.00 & 5.94 & 14.49 & 3.64 & 0.00 & 17.89 \\
\hline 36 & 32 & 0.00 & 0.00 & 0.00 & 0.00 & 6.06 & 10.83 \\
\hline 37 & 31 & 0.00 & 0.00 & 2.43 & 0.00 & 0.00 & 0.00 \\
\hline 38 & 30 & 0.00 & 0.00 & 1.48 & 11.33 & 0.00 & 0.00 \\
\hline 39 & 29 & 25.96 & 0.00 & 5.88 & 4.80 & 4.68 & 0.00 \\
\hline 40 & 28 & 0.00 & 3.93 & 0.00 & 0.00 & 0.00 & 0.00 \\
\hline 41 & 23 & 0.00 & 1.18 & 0.00 & 0.00 & 6.15 & 0.00 \\
\hline 42 & 22 & 0.00 & 0.00 & 2.11 & 0.00 & 0.00 & 4.47 \\
\hline 43 & 19 & 0.00 & 3.29 & 0.00 & 12.50 . & 7.02 & 0.00 \\
\hline 44 & 18 & 0.00 & 0.00 & 3.97 & 0.00 & 0.00 & 19.32 \\
\hline 45 & 17 & 0.00 & 0.00 & 0.00 & 0.00 & 9.52 & 0.00 \\
\hline 46 & 16 & 0.00 & 4.65 & 13.14 & 0.00 & 0.00 & 0.00 \\
\hline 47 & 14 & 28.09 & 0.00 & 0.00 & 0.00 & 0.00 & 0.00 \\
\hline
\end{tabular}

globulin and total protein fractions varied among the studied Vicia species and analyzed into 47, 19 and 38 bands respectively. Electrophoretic data for seed total proteins fractions represented in Table $1 \& 2$ and Fig. 1 show notable variations in total protein banding patterns of the studied Vicia species. Data from (Table 1) indicate
Vol. 3 No. 5 (May 2010)

ISSN: 0974- 6846 that the highest values of total amount percentage of bands were 22.92, 14.86, 15.02, 20.62 and 19.32 in $V$. sativa subsp. amphicarpa, V. articulata, V. ervilia, V. narbonensis and $V$. villosa, respectively, at band no. 26 (MW $46 \mathrm{KDa}$ ), band no. 27 (45 KDa), band no. 31 (39 $\mathrm{KDa})$, band no. 15 (58 KDa) and band no. 44 (18 KDa), respectively. In the same time, Table 2 shows that the highest value for seed total protein bands was recorded in V. sativa subsp. amphicarpa (22); whereas, the lowest one (14) was observed in both $V$. narbonensis and $V$. villosa. In addition, band no. 4 (MW $87 \mathrm{KDa}$ ), band no.11 (64 KDa), band no. 18 (55 KDa), band no. 29 (42 KDa) and band no. $40(28 \mathrm{KDa})$ are taxonomical markers for $V$. sativa subsp. amphicarpa. Band no. 3 (89 $\mathrm{KDa})$, band no. 7 ( $82 \mathrm{KDa})$, band no. $24(48 \mathrm{KDa})$, band no. $30(41 \mathrm{KDa})$ and band no. $37(31 \mathrm{KDa})$ are taxonomical markers for $V$. articulata; band no. 1 (97 $\mathrm{KDa})$, band no. 8 (73 KDa) and band no. $9(68 \mathrm{KDa})$ are taxonomical markers for $V$. ervilia; band no. 2 (92 KDa), band no. $14(59 \mathrm{KDa})$ and band no. $45(17 \mathrm{KDa})$ are taxonomical markers for $V$. narbonensis and band no. 5 (86 KDa) and band no.6 (83) are taxonomical markers for $V$. villosai. Concerning clustering analysis among the five studied Vicia species. The obtained data classified the studied Vicia species into four groups according to similarity percentage. The highest value of similarity percentage (82.35) was observed between both $V$. articulata and $V$. narbonensis.

\section{Albumin electrophoresis}

Data presented in (Table $3 \& 4$ ) and (Fig. $3 \& 4$ ) indicate that the highest values of total amount percentage of bands of albumin were 40.80, 38.16, 48.94, 35.91 and 40.89 in $V$. sativa subsp. amphicarpa, $V$. articulata, V. ervilia, V. narbonensis and V. villosa, respectively, at band no. 19 (MW $12 \mathrm{KDa}$ ), band no. 18 (14 KDa), band no. 16 (21 KDa), band no. 15 (22 KDa) and band no. 18 (14 KDa), respectively. Table 4 shows that, the highest value for seed albumin bands (5) was recorded in $V$. sativa subsp. amphicarpa, $V$. ervilia and $V$. villosa; whereas, the lowest one (4) was observed in both $V$. articulata and $V$. narbonensis. On the other hand, three polymorphic bands (band no. 6 (MW 37 $\mathrm{KDa}$ ), band no. 11 (30 KDa) and band no. 19 (12 KDa) are characteristic for $V$. sativa subsp. amphicarpa. Band no. $5(39 \mathrm{KDa})$ is taxonomical marker for $V$. articulata; band no. $10(31 \mathrm{KDa})$ is taxonomical marker for $V$. ervilia; bands no. 13,15 and $17(28,22$ \& $15 \mathrm{KDa})$ are taxonomical markers for $V$. narbonensis and band no. 2 $(81 \mathrm{KDa})$ is taxonomical marker for $V$. Villosa.

Results obtained from UPGMA clustering analysis for albumin fractions basis on the similarity polymorphism in (Fig. 4) separate the five studied Vicia species into four groups. The first group consists of $V$. ervilia and $V$. villosa with similarity $90.91 \%$, the second group $V$. sativa subsp. amphicarpa and $V$. narbonensis with similarity $88.89 \%$. Moreover, the third group $V$. sativa subsp. amphicarpa,
Research article

CIndian Society for Education and Environment (iSee)
"Genetic diversity of Vicia species" http://www.indjst.org
Sakr et al. Indian J.Sci.Technol. 
Table 2. Distribution of seed total protein bands in the studied Vicia species obtained by SDS-PAGE

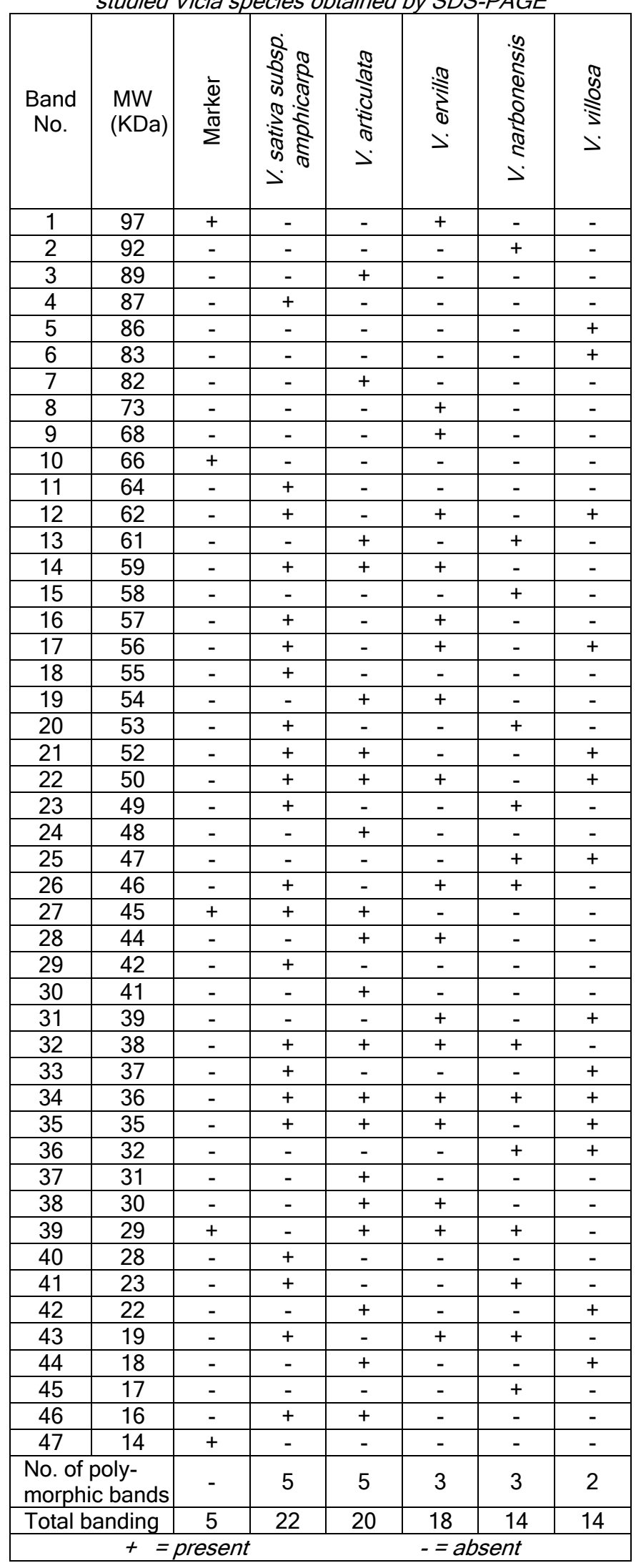

Vol. 3 No. 5 (May 2010)

ISSN: 0974- 6846

V. articulata and V. narbonensis with similarity $70.83 \%$. Finally, the fourth group $V$. sativa subsp. amphicarpa, $V$. articulata, $V$. ervilia, $V$. narbonensis and $V$. villosa with similarity $67.68 \%$.

Table 3. Seed albumin banding patterns of studied Vicia sativa sub species obtained by SDS-PAGE

\begin{tabular}{|c|c|c|c|c|c|c|c|}
\hline $\begin{array}{l}\text { Band } \\
\text { No. }\end{array}$ & $\begin{array}{l}\text { MW } \\
\text { (KDa) }\end{array}$ & 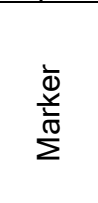 & 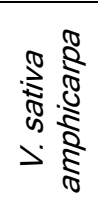 & 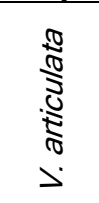 & 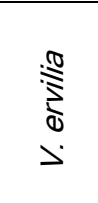 & 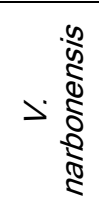 & 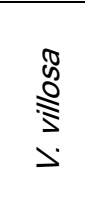 \\
\hline 1 & 97 & 14.05 & 0.00 & 0.00 & 0.00 & 0.00 & 0.00 \\
\hline 2 & 81 & 0.00 & 0.00 & 0.00 & 0.00 & 0.00 & 3.87 \\
\hline 3 & 66 & 12.17 & 0.00 & 0.00 & 0.00 & 0.00 & 0.00 \\
\hline 4 & 45 & 33.70 & 0.00 & 0.00 & 0.00 & 0.00 & 0.00 \\
\hline 5 & 39 & 0.00 & 0.00 & 32.18 & 0.00 & 0.00 & 0.00 \\
\hline 6 & 37 & 0.00 & 37.28 & 0.00 & 0.00 & 0.00 & 0.00 \\
\hline 7 & 35 & 0.00 & 0.00 & 0.00 & 25.53 & 0.00 & 10.95 \\
\hline 8 & 33 & 0.00 & 6.35 & 0.00 & 0.00 & 23.14 & 12.64 \\
\hline 9 & 32 & 0.00 & 0.00 & 17.37 & 5.12 & 0.00 & 0.00 \\
\hline 10 & 31 & 0.00 & 0.00 & 0.00 & 3.10 & 0.00 & 0.00 \\
\hline 11 & 30 & 0.00 & 8.00 & 0.00 & 0.00 & 0.00 & 0.00 \\
\hline 12 & 29 & 18.70 & 0.00 & 0.00 & 0.00 & 0.00 & 0.00 \\
\hline 13 & 28 & 0.00 & 0.00 & 0.00 & 0.00 & 29.45 & 0.00 \\
\hline 14 & 23 & 0.00 & 7.57 & 0.00 & 0.00 & 0.00 & 31.65 \\
\hline 15 & 22 & 0.00 & 0.00 & 0.00 & 0.00 & 35.91 & 0.00 \\
\hline 16 & 21 & 0.00 & 0.00 & 12.29 & 48.94 & 0.00 & 0.00 \\
\hline 17 & 15 & 0.00 & 0.00 & 0.00 & 0.00 & 11.49 & 0.00 \\
\hline 18 & 14 & 21.37 & 0.00 & 38.16 & 17.32 & 0.00 & 40.89 \\
\hline 19 & 12 & 0.00 & 40.80 & 0.00 & 0.00 & 0.00 & 0.00 \\
\hline
\end{tabular}

\section{Globulin electrophoresis}

Globulin banding patterns results are given in (Table 5 $\& 6$ ) and (Fig. $5 \& 6$ ). The highest values of total amount percentage of bands were 17.04, 18.58, 18.25, 20.33 and 26.84 at bands no. $26(35 \mathrm{KDa}), 18(47 \mathrm{KDa}), 14(54$ $\mathrm{KDa}), 19(46 \mathrm{KDa})$ and $20(45 \mathrm{KDa})$, respectively, for $V$. sativa subsp. amphicarpa, $V$. articulata, V. ervilia, $V$. narbonensis and $V$. villosa, respectively. Table 6 shows that the highest value for seed globulin bands (12) was recorded in $V$. sativa subsp. amphicarpa and $V$. narbonensis, whereas, the lowest one (8) was observed in $V$. villosa. Six polymorphic bands (band no. 7 (MW 73 $\mathrm{KDa})$, band no. 8 (66 KDa), band no. 10 (62 KDa), band no. $16(50 \mathrm{KDa})$, band no. 26 ( $35 \mathrm{KDa}$ ) and band no. 35 (17 KDa) are characteristic for $V$. sativa subsp. amphicarpa. Also, six bands (band no. 4 (MW $84 \mathrm{KDa}$ ), band no. 5 (77 KDa), band no. 18 (47 KDa), band no. 24 (37 KDa), band no. 30 (28 KDa) and band no. 33 (19 $\mathrm{KDa}$ ) are characteristic for $V$. articulata .Band no. 2 (92 $\mathrm{KDa}$ ), band no. 9 (MW $65 \mathrm{KDa})$, band no. 12 (57 KDa), band no. 14 (54 KDa), band no. 23 (42 KDa), band no. $25(36 \mathrm{KDa})$ and band no. $31(26 \mathrm{KDa})$ are taxonomical markers for $V$. ervilia; bands no. 6, 15, 22 and $32(75,53$, $43 \& 25 \mathrm{KDa}$ ) are taxonomical markers for $V$. narbonensis. As the aforementioned trends which were found for total protein and albumin patterns the cluster
Research article

CIndian Society for Education and Environment (iSee)
"Genetic diversity of Vicia species" http://www.indjst.org
Sakr et al. Indian J.Sci.Technol. 
analysis differentiate the globulin fractions into four groups. V. articulata and V. villosa located in the first cluster with highest similarity $(94.74 \%)$ while the lowest similarity $(66.66 \%)$ between V. ervilia and the others Vicia species under investigation.

Table 4. Distribution of seed albumin bands in the studied Vicia sativa sub species obtained by SDS-PAGE

\begin{tabular}{|c|c|c|c|c|c|c|c|}
\hline & & & & & & & \\
\hline $\begin{array}{c}\text { Band } \\
\text { No. }\end{array}$ & $\begin{array}{l}\text { MW } \\
\text { KDa }\end{array}$ & 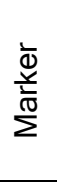 & 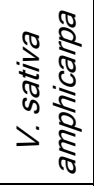 & $\begin{array}{c}\frac{\pi}{\pi} \\
\frac{0}{3} \\
0 \\
0 \\
0\end{array}$ & 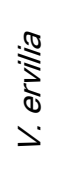 & 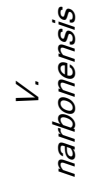 & 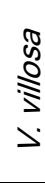 \\
\hline 1 & 97 & + & - & - & - & - & - \\
\hline 2 & 81 & - & - & - & - & - & + \\
\hline 3 & 66 & + & - & - & - & - & - \\
\hline 4 & 45 & + & - & - & - & - & - \\
\hline 5 & 39 & - & - & + & - & - & - \\
\hline 6 & 37 & - & + & - & - & - & - \\
\hline 7 & 35 & - & - & - & + & - & + \\
\hline 8 & 33 & - & + & - & - & + & + \\
\hline 9 & 32 & - & - & + & + & - & - \\
\hline 10 & 31 & - & - & - & + & - & - \\
\hline 11 & 30 & - & + & - & - & - & - \\
\hline 12 & 29 & + & - & - & - & - & - \\
\hline 13 & 28 & - & - & - & - & + & - \\
\hline 14 & 23 & - & + & - & - & - & + \\
\hline 15 & 22 & - & - & - & - & + & - \\
\hline 16 & 21 & - & - & + & + & - & - \\
\hline 17 & 15 & - & - & - & - & + & - \\
\hline 18 & 14 & + & - & + & + & - & + \\
\hline 19 & 12 & - & + & - & - & - & - \\
\hline $\begin{array}{l}\text { polyn } \\
\text { band }\end{array}$ & $\begin{array}{l}\text { rphic } \\
\text { (No.) }\end{array}$ & - & 3 & 1 & 1 & 3 & 1 \\
\hline Total & nding & 5 & 5 & 4 & 5 & 4 & 5 \\
\hline
\end{tabular}

\section{Protein content}

The amount of albumin, globulin and total protein determined in the seeds of Vicia species under investigation, as well as, the percentage of both albumin and globulin in seed protein are illustrated in Table 7. It is evident that the highest values of albumin, globulin and total protein amounts $(4.7,40.3 \& 59.1 \mathrm{mg} / \mathrm{g}$ dry wt. respectively) were observed in $V$ ervilia, $V$. villosa and $V$. narbonensis, respectively. On the other hand, the minimal value of albumin $(2.6 \mathrm{mg} / \mathrm{g}$ dry wt.) was recorded in $V$. articulata, while, globulin and total protein $(21.6 \& 24$ $\mathrm{mg} / \mathrm{g}$ dry wt.) were recorded in $V$. sativa subsp. amphicarpa. In the meantime, the percentages of albumins to total protein and globulins to total protein were varied according to the studied Vicia species. The highest percentages of albumins to total protein $(15.2 \%)$ and globulins to total (89.9\%) were recorded in $V$ articulata. Whereas, the lowest one was $5.7 \%$ for albumins to total protein in $V$. narbonensis and $52.8 \%$ for globulin to total protein in $V$. ervilia.
Vol. 3 No. 5 (May 2010)

ISSN: 0974- 6846
Table 5. Seed globulin banding patterns of studied Vicia sativa sub species obtained by SDS-PAGE

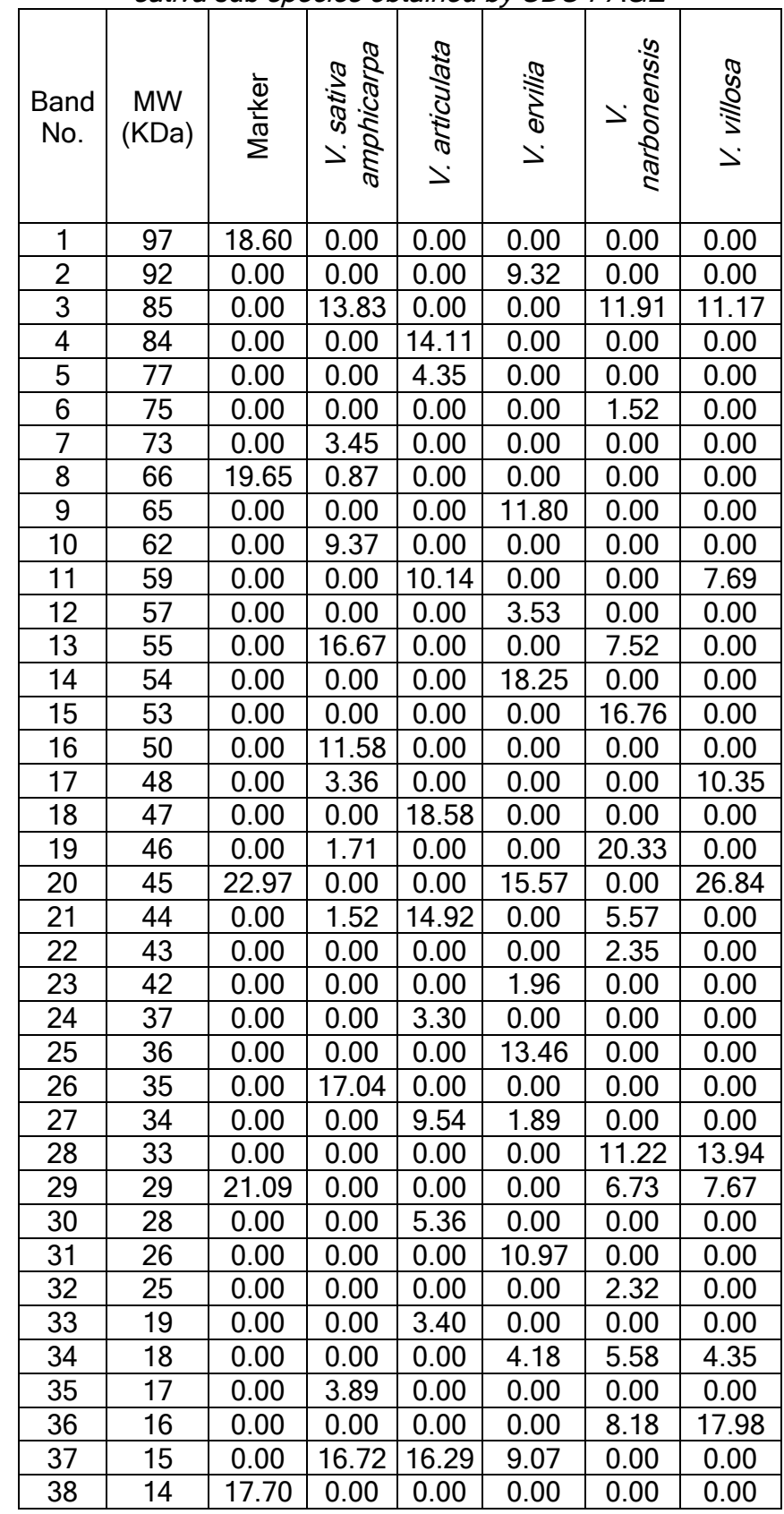

\section{Amino acids}

The amounts of different amino acids ( $\mu \mathrm{mol} / \mathrm{g}$ dry wt.) in the seeds of various five Vicia species were presented in Table 8. Results in these Tables show obvious increments in the amount of the amino acids; lysine $(0.74)$, valine $(0.28)$, threonine $(0.23)$, isoleucine $(0.019)$, methionine (0.034), glycine $(0.38)$, alanine $(0.32)$, serinine $(0.32)$, phenylalanine $(0.19)$ and histidine $(0.11)$ $\mu \mathrm{mol} / \mathrm{g}$ dry wt. were recorded in $V$. articulata in comparison with the other amino acids and Vicia species. Whereas, the lowest values for lysine (0.10), Lucien
Research article

CIndian Society for Education and Environment (iSee)
"Genetic diversity of Vicia species" http://www.indjst.org
Sakr et al. Indian J.Sci.Technol. 
Table 6. Distribution of seed globulin bands in the studied Vicia sativasub species obtained by SDS-PAGE

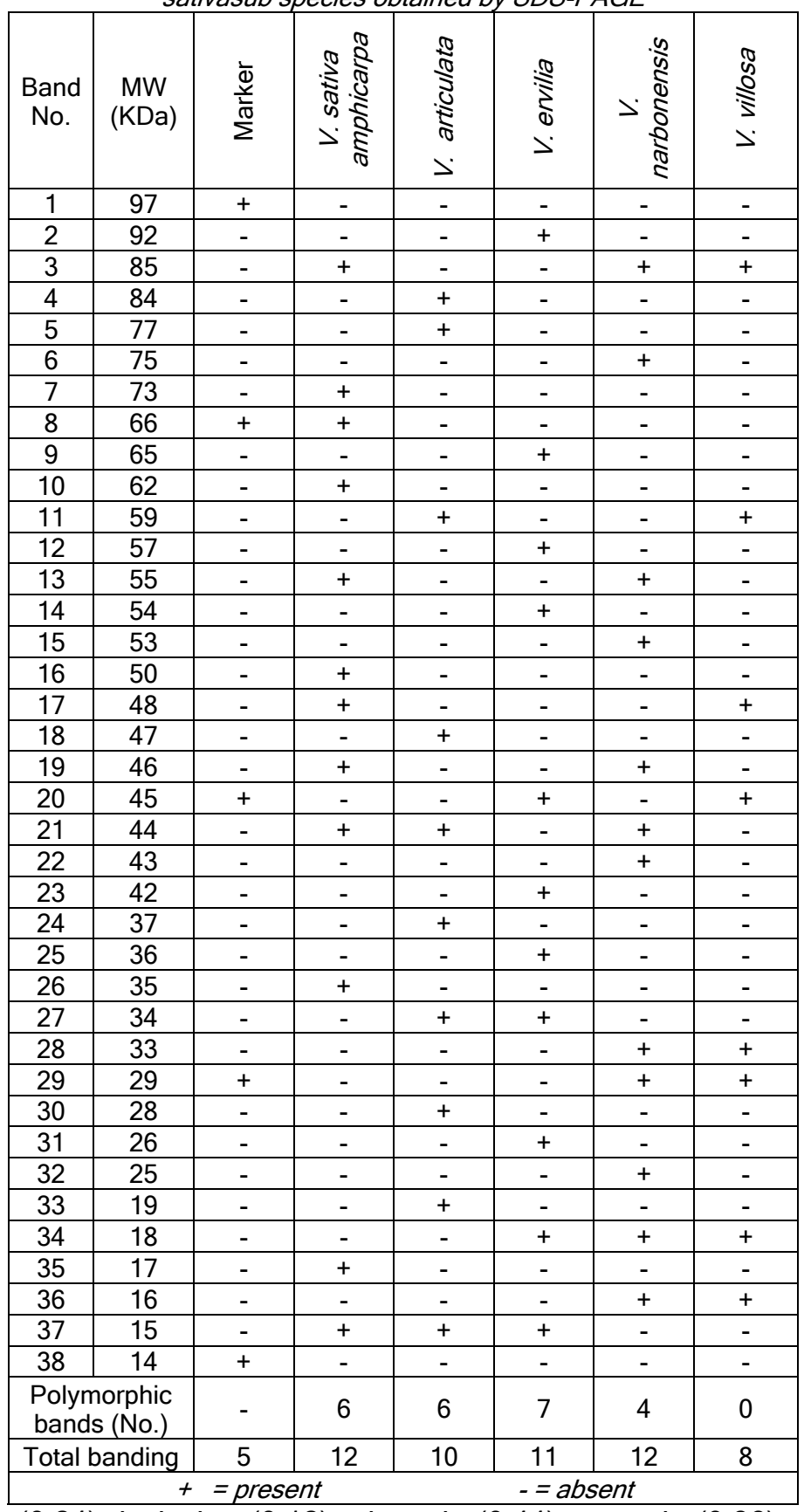

(0.24), isolucine $(0.12)$, glutamic $(0.44)$, aspartic $(0.36)$, glycine $(0.26)$, serine $(0.21)$, phenylalanine $(0.13)$, histidine (0.07) and asparagines (0.006). Glutamine was absent in $V$. ervilia. The highest value for total amino acids (4.70) was recorded in V. articulata; while the lowest one (2.77) was found in $V$. narbonensis.

\section{Discussion}

The present investigation reveals that the wild Vicia species varied with seed protein and amino acid content as observed from total protein, albumin, globulin, and
Vol. 3 No. 5 (May 2010)

ISSN: 0974- 6846

Table 7. Protein content and its percentage in the five studied Vicia species seeds

\begin{tabular}{|c|c|c|c|c|c|c|}
\hline \multicolumn{2}{|c|}{ Species } & 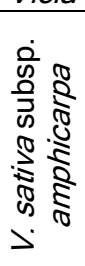 & 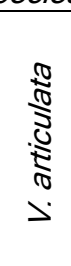 & 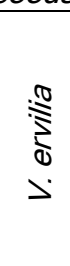 & 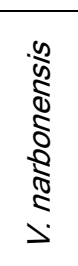 & 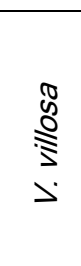 \\
\hline \multirow{3}{*}{ 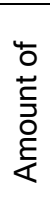 } & $\begin{array}{l}\text { Albumin (mg/g } \\
\text { dry wt.) }\end{array}$ & 3.6 & 2.6 & 4.7 & 4.2 & 3.6 \\
\hline & $\begin{array}{l}\text { Globulin (mg/g } \\
\text { dry wt.) }\end{array}$ & 21.6 & 26.4 & 39.4 & 31.2 & 40.3 \\
\hline & $\begin{array}{l}\text { Total protein } \\
\text { (mg/g dry wt.) }\end{array}$ & 24.0 & 45.6 & 57.6 & 59.1 & 45.8 \\
\hline \multicolumn{2}{|c|}{$\begin{array}{l}\text { \% Albumin to total } \\
\text { protein }\end{array}$} & 8.0 & 15.2 & 7.1 & 5.7 & 7.9 \\
\hline \multicolumn{2}{|c|}{$\begin{array}{c}\text { \% Globulin to total } \\
\text { protein }\end{array}$} & 68.3 & 89.9 & 52.8 & 57.9 & 88.1 \\
\hline
\end{tabular}

Table 8. The amino acids composition of the studied Vicia species seeds (calculated as $\mu$ mol/g dry wt.)

\begin{tabular}{|c|c|c|c|c|c|}
\hline Species & 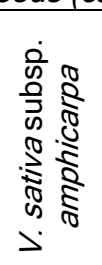 & 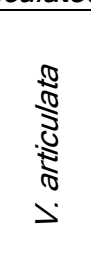 & 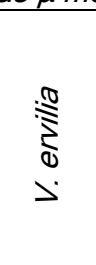 & 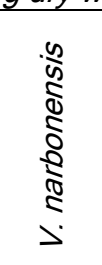 & 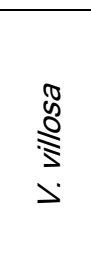 \\
\hline Lysine & 0.280 & 0.740 & 0.240 & 0.100 & 0.410 \\
\hline Leucine & 0.320 & 0.310 & 0.250 & 0.240 & 0.300 \\
\hline Valine & 0.230 & 0.280 & 0.180 & 0.170 & 0.240 \\
\hline Threonine & 0.190 & 0.230 & 0.150 & 0.140 & 0.210 \\
\hline Isoleucine & 0.150 & 0.190 & 0.130 & 0.120 & 0.170 \\
\hline Tyrosine & 0.020 & 0.110 & 0.170 & 0.040 & 0.002 \\
\hline Methionine & 0.022 & 0.034 & 0.011 & 0.017 & 0.021 \\
\hline Glutamic acid & 0.620 & 0.590 & 0.570 & 0.440 & 0.540 \\
\hline Asparatic acid & 0.630 & 0.540 & 0.440 & 0.360 & 0.490 \\
\hline Glycine & 0.370 & 0.380 & 0.270 & 0.260 & 0.340 \\
\hline Alanine & 0.260 & 0.320 & 0.160 & 0.250 & 0.290 \\
\hline Serinine & 0.300 & 0.320 & 0.220 & 0.210 & 0.280 \\
\hline Arginine & 0.340 & 0.350 & 0.200 & 0.220 & 0.290 \\
\hline Phenylalanine & 0.150 & 0.190 & 0.140 & 0.130 & 0.170 \\
\hline Histidine & 0.100 & 0.110 & 0.080 & 0.070 & 0.090 \\
\hline Asparagine & 0.016 & 0.008 & 0.014 & 0.006 & 0.013 \\
\hline Glutamine & 0.008 & 0.004 & 0.000 & 0.002 & 0.003 \\
\hline $\begin{array}{l}\text { Total determined } \\
\text { amino acids }\end{array}$ & 4.006 & 4.706 & 3.225 & 2.775 & 3.859 \\
\hline
\end{tabular}

amino acid estimations. The variation also reflected in albumin/total protein and globulin/total protein ratio of the seed powder. This protein variation might have resulted in the polymorphism bands, which gave each species its specific electrophoregram for total protein, albumin and globulin. Such electrophoregram of the studied species can be used as a tool for identifying the genetic diversity in Vicia species. These results support the validity of seed protein as a powerful tool for Vicia species identification and clarifying taxonomic relationships
Research article

CIndian Society for Education and Environment (iSee)
"Genetic diversity of Vicia species" http://www.indjst.org
Sakr et al.

Indian J.Sci.Technol. 
Fig. 1. SDS-PAGE for seed total protein patterns of the five studied Vicia spp.

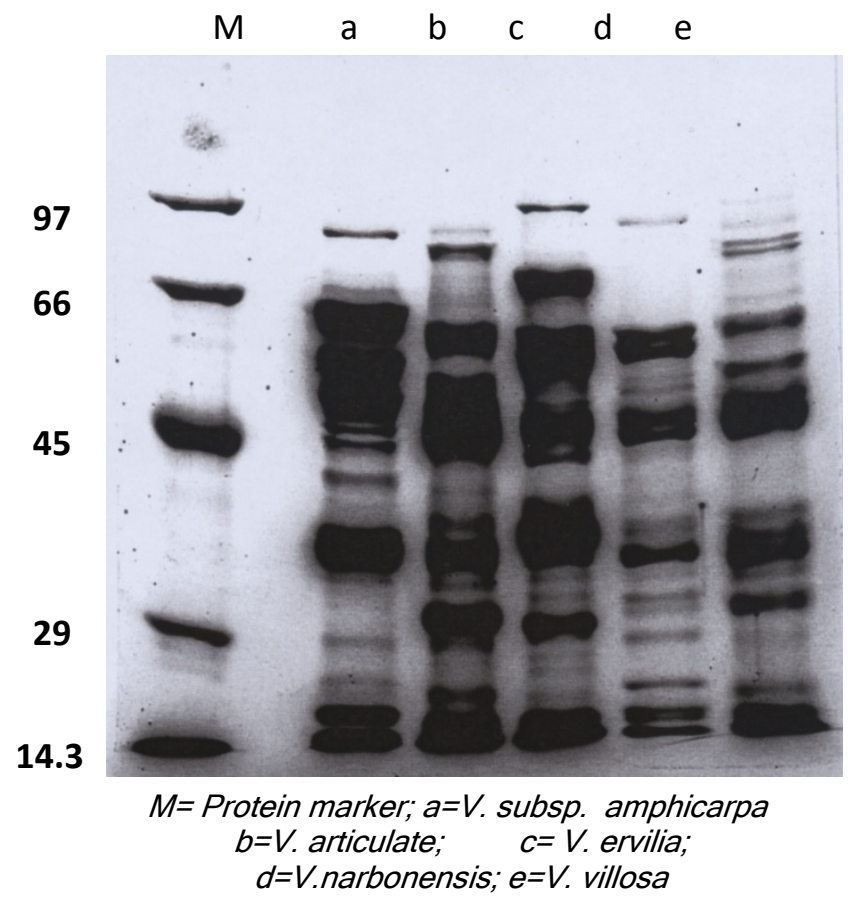

Fig. 3. SDS-PAGE seed albumin patterns of the five studied Vicia species

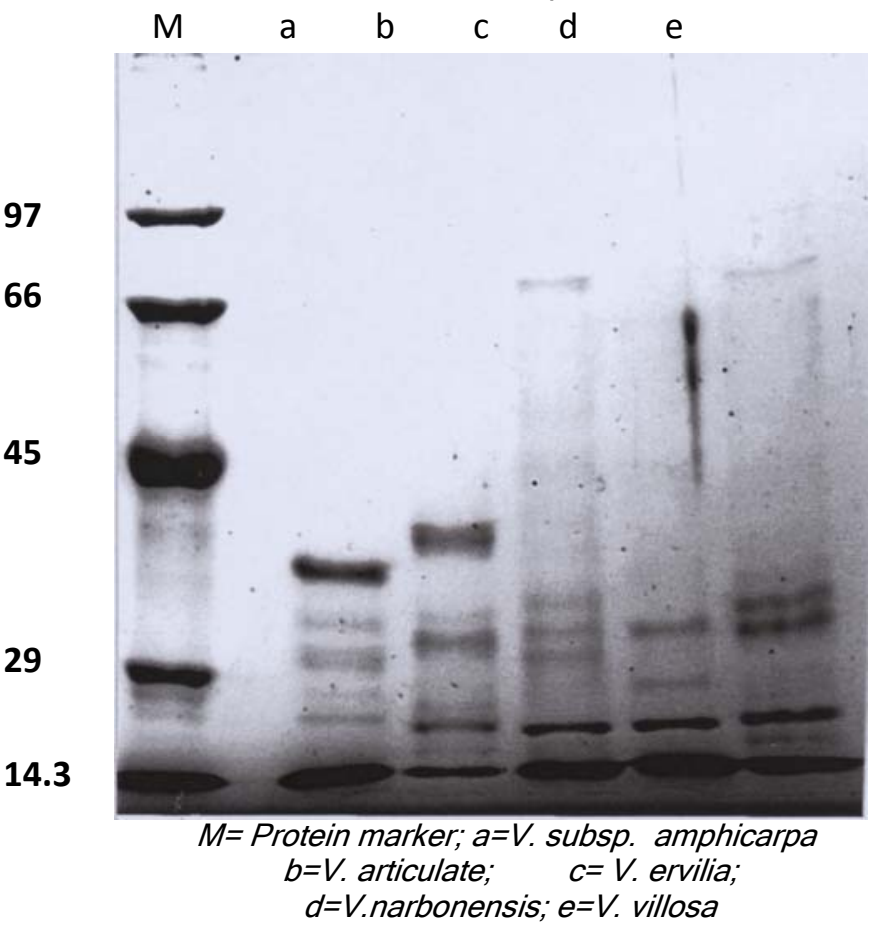

Fig. 2. Dendogram resulted from UPGMA clustering analysis based on the similarity polymorphism of total Protein patterns of the five studied Vicia spp. using SDS-PAGE

UPGMA Clustering using Simple Band Match (Tolerance:3.20\%) May 172008

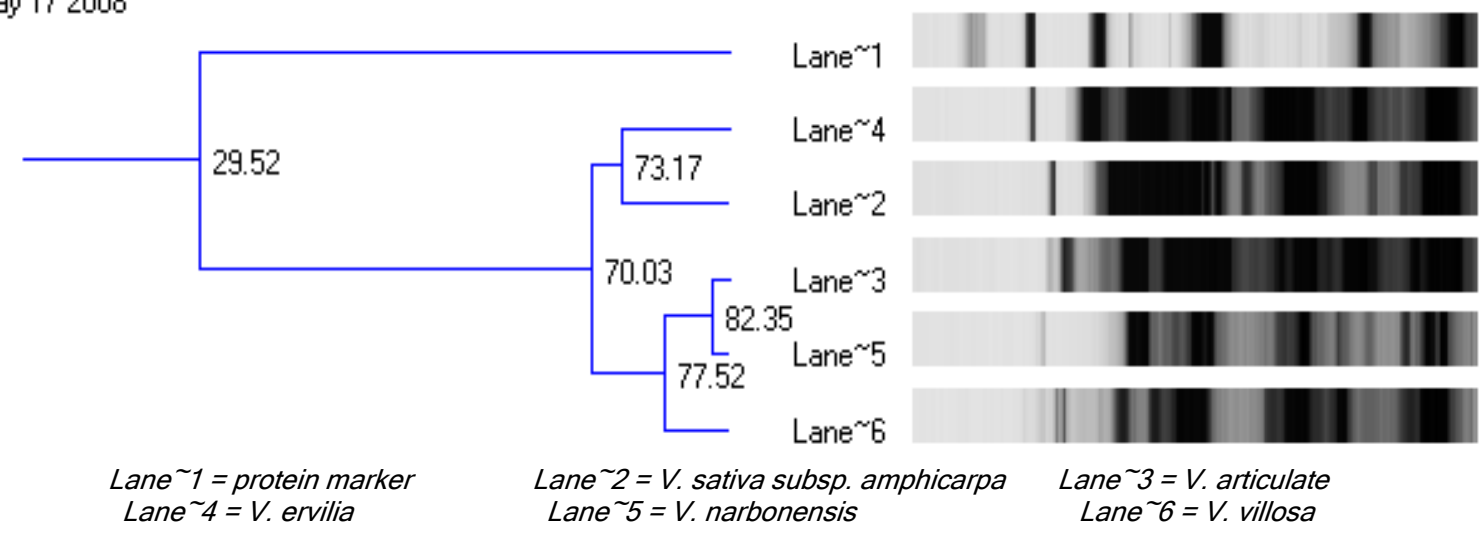


Fig. 4. Dendogram resulted from UPGMA clustering analysis based on the similarity polymorphism of albumin patterns of the five studied Vicia spp. using SDS-PAGE

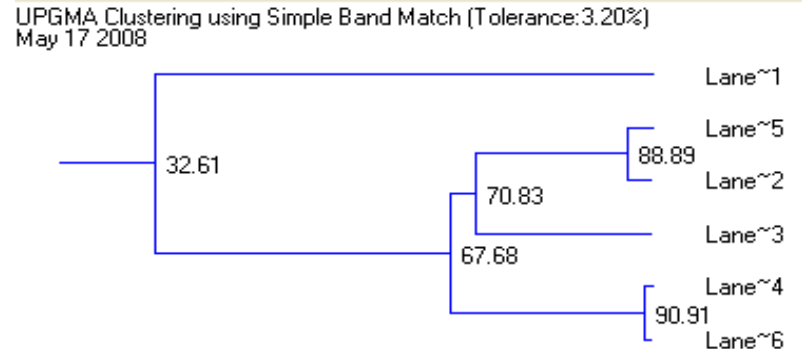

Lane $\sim$ 1 $=$ protein marker Lane $2=V$. sativa subsp. Amphicarpa Lane $\sim$ = V. ervilia

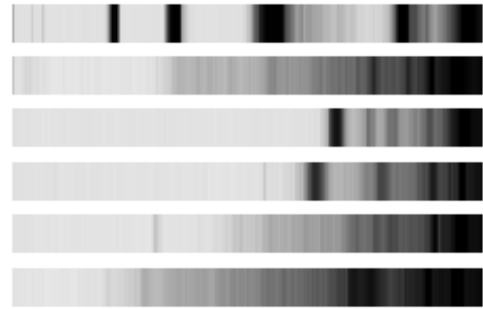

Lane $\sim$ 3 $=$. articulata Lane $\sim$ G $=$ V. villosa

Fig. 5. SDS-PAGE seed globulin patterns of the

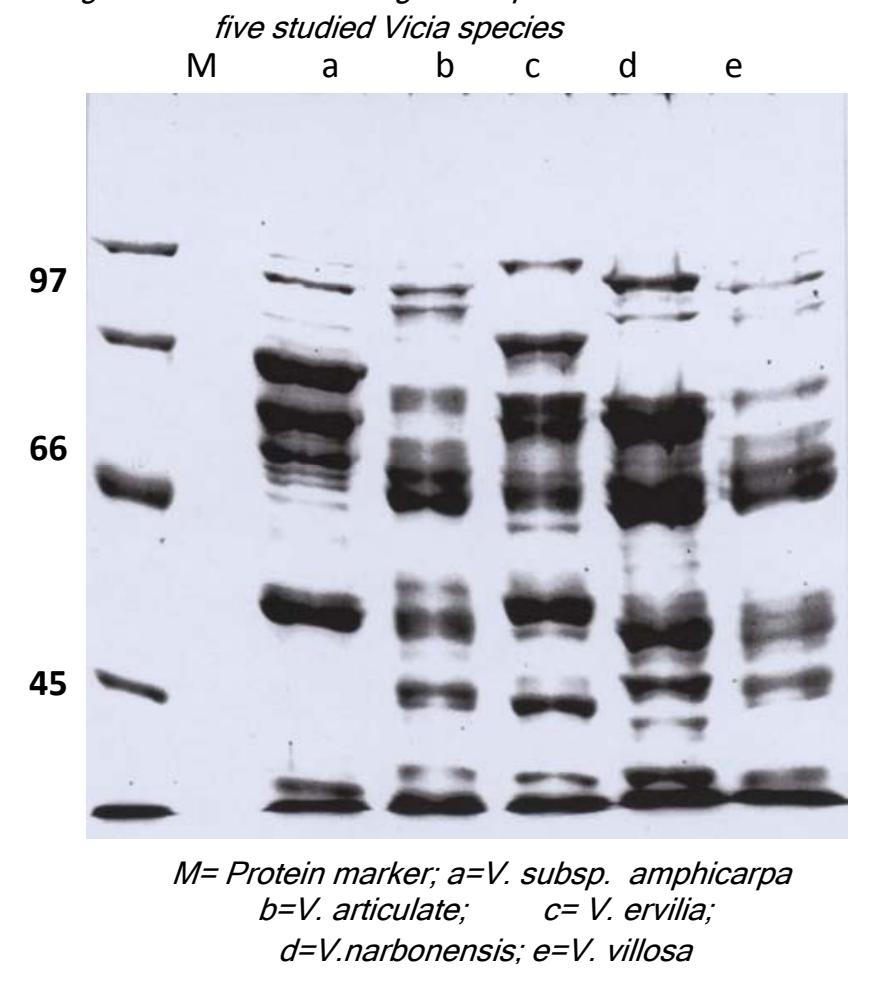

Fig. 6. Dendogram resulted from UPGMA clustering analysis based on the similarity polymorphism for alobulin patterns of the five studied Vicia species using SDS-PAGE. UPGMA. Clustering using Simple Band Match (Tolerance: $3.20 \%$ ) May 172008

Research article

CIndian Society for Education and Environment (iSee)

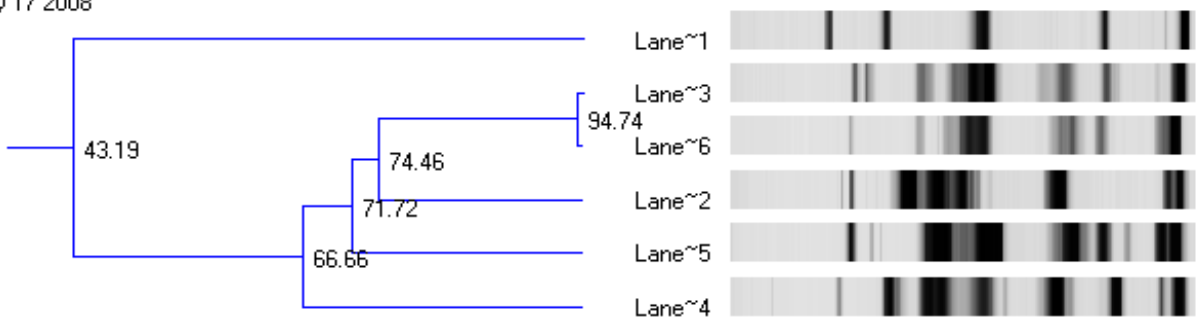

Lane $\sim$ 1 $=$ protein marker Lane $2=$ V. sativa subsp. Amphicarpa Lane $\sim 3=V$. articulata

"Genetic diversity of Vicia species" http://www.indjst.org
ISSN: 0974- 6846 
(Singor et al., 2005; Mustafa et al., 2006; Thanh et al., 2006; Sammour et al., 2007). Also the wide variation observed for seed albumins, globulins and amino acids, which is a genetic trait (Sakr, 1995; Hassan, 1997; Sammour et al., 2007). In addition, Vargas et al. (2001) and Mirali et al. (2007) attributed the differences between Vicia and Phaseolus species polymorphism, result from DNA sequences that code for peptides involved in posttranscription changes.

\section{References}

1. Boulos L (1999) Flora of Egypt. Al Hadara Publ., Cairo, Egypt. 1, 341-348.

2. Bailey CJ and Boulter D (1970) The structure of legumin, a storage protein of Bean (Vicia faba) seeds. Eur. J. Biochem. 17, 460-466.

3. Bradford MM (1976) A rapid and sensitive method for the quantification of microgram quantities of protein utilizing the principle of protein dye binding. Anal. Biochem. 72, 248-254.

4. Daussant J, Mosse J and Vaughan J (1983) Breeding for protein quantity and protein quality in seed crops. In: Seed protein. Springer, Berlin. pp: 223-249.

5. Hassan AE (1997) Comparative studies on some species of the genus Vicia L. Ph. D. Thesis. Suez Canal University. Fac. of Agriculture, Agri. Botany Dept. p:134.

6. Jackson P, Boulter D and Thurman DA (1969) A comparison of some properties of vicilin and legumin isolated from seeds of Pisum sativum, Vicia faba and Cicer arietinum. New Phytol. 68, 25-30.

7. Juo P and Stotzky G (1970) Electrophoretic patterns of globulin and albumin in conifer seeds. Can. J. Bot. 48, 1911-1912.

8. Ladizinsky GR and Waines GR (1982) Seed protein polymorphism in Vicia faba agg. (Fabaceae) P1. Syst. Evol. 141, 1-5.

9. Laemmli UK (1970) Cleavage of structural proteins during the assembly of the head of Bacteriophage T4. Nature. 227, 660-685.

10. Miege MN (1982) Protein types and distribution. In: Nucleic acids and proteins in plant. Boulter C \& Parthier B (Eds.), Springer, Berlin. pp: 291-315.

11.Mirali N, El-Khouri S and Rizq F (2007) Genetic diversity and relation in some Vicia species as determined by SDS-PAGE of seed proteins. Biologia Plantarum. 51(4), 660-666.

12. Moore S and Stein WH (1963) Chromatographic determination of amino acids by the use of automatic recording equipment. Methods in Enzymology. Colowick SP \& Kaplan NO (Eds.), AP, NY. 6, 819-823.

13. Muntz K, Horstman C and Schlesier B (1986) Seed proteins and their genetics in Vicia faba L. Biol Zentralbl. 105, 107-120.

14. Mustafa AZMA, Badr A, El-Galaly MA, Mobarak AA and Hassan MG (2006) Genetic diversity among Ocimum population in Egypt as reflected by morphological, seed proteins and isozyme
Vol. 3 No. 5 (May 2010)

ISSN: 0974- 6846

polymorphism. Int. J. Bot. 2, 261-269.

15. Mustafa AZM (2007) Genetic variation among Egyptian cultivars of Vicia faba L. Pak. J. Bio. Sci. 10(23), 4204-4210.

16. Potokina E, Duncan AV, Eggi EE and Tomooka N (2000) Population diversity of the Vicia sativa agg. (Fabaceae) in the flora of the former USSR deduced from RAPD and seed protein analyses. Genetic Res. Crop Evol. 47, 171-183.

17.Przybylska J, Mantéuffel R and Bisby F (1992) Immunological investigations on distribution of the $2 \mathrm{~s}$ albumin in the Leguminoseae (Papilionoideae). Biochem. Syst. Ecol. 20(7), 639-655.

18. Rao R (1984) Chromosome mutants in Pisum sativum: Composition of seed proteins. Genet. Agrar. 38, 357-367.

19.Rohlf FJ (1993) NTSYS-pc, Numerical taxonomy and multivariate analysis system. Version 2.1. Exeter Publ., Setauket, NY.

20.Sakr MM (1995) The application of electrophoretic data from isozymes (esterase \& superoxide dismutase) and protein in classification of some sesame (Sesamum indicum) genotypes. Egypt. J. Appl. Sci. 10 (5), 661-680.

21.Sammour R, Mustafa A, Badr S and Taher W (2007) Genetic variation in accession of Lathyrus sativus $L$. Acta Bot. Croat. 66, 1-13.

22.Singor CL, Gallardo K, Prosperi JM, Salon C, Quillien L, Thomposon R and Duc G (2005) Genetic diversity for seed protein composition in Medicago truncatula. Plant Genet. Resour. 3, 59-71.

23. Täckholm V (1974) Students' flora of Egypt. Publ. of Cairo Univ. Herb. Coop. Co. Beirut, 4I6-418.

24.Thanh VC, Phuong PV, Uyen PHH and Hien PP (2006) Application of protein electrophoresis SDSPAGE to evaluate genetic purity and diversity of several varieties. Proc. of Inter. Workshop on Biotechnology in Agriculture; Nong Lam Univ. Ho Chi Minch City, Oct. 20-21, pp:192-194.

25. Tucci M, Capparelli R, Costa A and Rao R (1991) Molecular heterogeneity and genetics of Vicia faba seeds storage proteins. Theor. App. Genet. 81, 50-58.

26. Vargas EM, Macaya G, Baudoin JP and Rocha OJ (2001) Case studies on breeding systems and its consequences for germplasm conservation: 3 . Electrophoretic mobility of phaseolins in wild populations of Lima beans (Phaseolus lunatus L.) in the central valley of Costa Rica. Genet. Resour. Crop Evol. 48, 109-120.

27.Vaughan JG (1983) The use of seed proteins in taxonomy and phylogeny. In: Seed proteins. Daussant J, Mosse J \& Vaughan J (Eds.), AP, London, NY. pp:135-150.

28. Young ND, Mudgeand J and Ellis THN (2003) Legume genomes: more than peas in a pod. Curr. Opin. Plant Biol. 6, 199-204.
Research article

CIndian Society for Education and Environment (iSee)
"Genetic diversity of Vicia species" http://www.indjst.org
Sakr et al. Indian J.Sci.Technol. 